\title{
Penegakan Hukum dalam Era Reformasi
}

\author{
Abrar Saleng
}

\begin{abstract}
The law enforcement in the reform era has not been achievable even the trust of the public on law and the law enforcement tend to lower and lower. In the reform era public directly witness how poor the law and the judicature are going on. The upholder law still use the out of date paradigm but they use the new fashion.
\end{abstract}

\section{Pendahuluan}

Indonesia adalah negara hukum (rechtstaat). Negara yang berdasar atas hukum berarti hukum ditempatkan sebagai panglima atau dengan kata lain pengakuan dan aplikasi supremasi hukum atau "rule of law". Implementas "rule of law" adalah aturan-aturan yang menitikberatkan pada pembatasan-pembatasan kekuasaan agar tidak terjadi absolutisme yang mengarah kepada "onrechmatige daad" bahkan dapat menjadi tindakan "ongrondwetting" (bertentangan dengan undang-undang dasar)

Pengaturan dan pembatasan kekuasaan harus tercermin dalam suatu peraturan yang berintikan keadilan. Peraturan yang berintikan keadilan merupakan salah satu prasyarat berhasilnya pembangunan, sebagaimana yang diamanatkan dalam Pembukaan UUD 1945. Amanat yang dimaksud adalah bahwa Pemerintah Negara Indonesia berkewajiban melindungi segenap bangsa Indonesia, memajukan kesejahteraan umum, mencerdaskan kehidupan bangsa dan ikut melaksanakan ketertiban umum, yang berdasarkan perdamaian abadi dan keadilan sosial.

Indonesia sebagai negara yang mengakui supremasi hukum membawa konsekuensi bahwa sistem pemerintahannya harus; (1) Menjunjung tinggi hak asasi manusia dan menjamin segenap warga negara memiliki persamaan kedudukannya dalam hukum dan pemerintahan, serta wajib menjunjung tinggi hukum dan pemerintahan itu.; (2) Memegang teguh asas legalitas, dalam semua aspek kehidupan kenegaraan yang meliputi aspek politik, sosial-budaya, ekonomi, dan pertahanan-keamanan.

Kedua hal tersebut di atas merupakan ciri-ciri negara hukum. Menempatkan pengakuan dan perlindungan hak asasi 
manusia sebagai ciri negara hukum yang pertama, memiliki konsekuensi bahwa di dalam negara hukum, hak asasi manusia harus diberikan prioritas utama.

Perlindungan Hak Asasi Manusia (HAM), penegakan supremasi hukum dengan peradilan yang bebas serta asas legalitas, hanya dijadikan sebagai slogan yang dengan rajinnya diucapkan oleh para penguasa dan petinggi hukum. Sejalan dengan permasalahan dan pertanyaan-pertanyaan yang sering dilontarkan oleh berbagai kelompok masyarakat bangsa mengenai keterpurukan hukum merupakan wujud keprihatinan dan kepedulian yang harus ditindaklanjuti. Upaya yang dapat dilakukan adalah dengan menghimpun sebanyak mungkin data dan informasi yang aktual dan akurat mengenai permasalahan-permasalahan hukum yang sedang dihadapi masayarakat. Kemudian dari data dan informasi yang ada, dirumuskan konsepsi dan rencana strategis berkenaan dengan penegakan hukum (law enforcement) yang diyakini sebagai syarat mutlak keberhasilan pelaksanaan program pemerintah.

Dalam mengkaji Penegakan Hukum dalam Era reformasi, tulisan ini akan mengkaji hubungan antara: Penegakan hukum dan Supremasi Hukum, Subtantial justice dan formal justice, Kepastian hukum dan Kepastian Undang-undang serta Persamaan dan Keadilan.

\section{Penegakan Hukum dan Supremasi Hukum}

Apabila dicermati, kondisi objektif penegakan hukum dalam negara hukum Indonesia yang secara konsepsional menjunjung tinggi supremasi hukum, maka dapat dikatakan bahwa masih jauh dari kenyataan. Masih pantaskah kita bicara dan mengklaim bahwa kita menjunjung tinggi supremasi hukum, tentu pertanyaan selanjutnya adalah supremasi hukum macam apa?

Merebaknya penyimpangan terhadap hukum dalam berbagai bentuk korupsi, kulusi, nepotisme, kekerasan, kerusuhan yang didalamnya diikuti dengan penganiayaan, pembunuhan, pencurian, pemerkosaan pada semua tingkat atau level masyarakat adalah suatu bukti buruknya tingkat kepercayaan warga masyarakat terhadap pemerintah dan penegak hukum. Tentu pertanyaan selanjutnya ialah bagaimana cara yang terbaik untuk mengembalikan kepercayaan warga masyarakat, dan masyarakat luar (calon investor) terhadap hukum dan penegak hukum? Salah satu cara yang baik dan efektif menurut Achmad Ali' ialah membersihkan sosok sapu kotor yang masih bergentayangan di republik ini, sebab mengingat kondisi pemerintah Indonesia dalam situasi tranplacement yaitu suatu pemeritahan hasil kombinasi dari penguasa baru dengan sosok-sosok bagian dari rezim lama yang otoriter. Bergabungnya penguasa baru dan person rezim lama, mau tidak mau menciptakan situasi konflik yang tak berkesudahan.

${ }^{1}$ Achmad Ali, "Hakikat limu Hukum dan Solusi dari Keterpurukan Hukum di Indonesia", makalah Catatan Hukum, 2001, hlm. 29 
Bagi perilaku aparat penegak hukum, mencakup polisi, pengacara, jaksa dan hakim, agar dapat mengembalikan kepercayaan warga masyarakat, seyogyanya dalam menjalankan tugasnya lebih banyak bertanya pada hati nuraninya (conscience), ketimbang pada perutnya. Artinya hukum sudah saatnya dikembalikan pada akar moralitas, kultural dan religiusnya.

\section{Substantial justice dan formal justice}

Hukum merupakan sub sistem dalam sistem kehidupan bernegara sebagaimana dituliskan $\mathrm{Raz}^{2}$ dalam bukunya yang berjudul The Concept of $A$ Legal System, antara lain menyatakan bahwa sebagai salah satu sistem, hukum akan mempengaruhi kinerja sistemsistem lain dalam kehidupan bernegara. Negara yang sistem hukumnya demokratis akan menciptakan kehidupan demokratis dalam segala bidang kehidupan. Demokratisasi hukum ditentukan oleh strategi pembangunan hukum yang dianut oleh suatu negara.

Dari perspektif sejarah dikenal dua macam strategi pembangunan hukum yang menonjol dan berpengaruh. Kedua strategi pembangunan hukum yang dimaksud ditulis oleh Nonet dan Selznick, ${ }^{3}$ dalam bukunya Law and Society in Transition in Toward Responsive Law sebagai berikut:

a. Strategi pembangunan hukum "ortodoks", melahirkan tipe hukum "represif". Tipe hukum ini pada dasamya melihat hukum sebagai alat kekuasaan agar dapat mempertahankan status quo, berusaha meminimalisasi arus tuntutan perubahan, termasuk upaya membentengi arus tuntutan perubahan dari publik yang cenderung dianggap dapat mengganggu lestarinya kekuasaan. Ciri yang paling menonjol menurut Nonet dan Selznick ialah adanya dominasi negara dan lembaga-lembaganya. Hukum dan pranata-pranatanya cenderung menjadi instrumen yang ampuh untuk melaksanakan ideologi negara, hukum dijadikan kekuatan instrumental diskresi. Dalam strategi pembangunan hukum ortodoks, penguasa resmi mengidentifikasikan kepentingan sebagai kepentingan masyarakat, karena hukum pada kenyataannya melambangkan disprivilese dengan menekankan kewajiban dan tanggung jawab bukan pada hak-hak yang dimiliki golongan yang tidak berkuasa. Hukum dijadikan sekedar .alat untuk memenuhi kebutuhan para aktor sosial.

Proses pembentukan hukum pada strategi pembangunan hukum ortodoks tidak dilandasi oleh aspirasi yang berkembang dalam masyarakat, berbagai cara rekayasa atau manipulasi dilakukan agar terkesan bahwa suatu produk perundangundangan adalah aspirasi seluruh rakyat.

b. Strategi pembangunan hukum responsif, penekanannya adalah hukum sebagai legitimasi keinginan atau nilai-nilai yang hidup dan berkembang dalam masyarakat. Ciri-ciri pembangunan hukum responsif adalah masyarakat

2 Joseph Raz, The Consept of A Legal Syatem, (New York: Clarandom Press Oxford, 1980), him. 112-113

${ }^{3}$ Philippe Nonet dan Philippe Selznick, Law and Society in Transition in Toward Responsive Law, (New York: Harper Colophon Book, 1997), him. 198 
berperan, negara tidak dominan.

Sejalan dengan pemikiran Nonet dan Selznik di atas, $\operatorname{Dias}^{4}$ (1989), antara lain menyatakan bahwa di negara-negara dunia ketiga pada umumnya hukum telah dimanfaatkan sebagai instrumen yang begitu ampuh untuk mewujudkan program-program penguasa. Hal semacam ini menyebabkan fungsionalisasi hukum tidak proporsional bahkan lebih dari itu hukum menjadi tidak supremasi, hukum dikesampingkan dengan alasan politis tertentu.

Selanjutnya Nonet dan Selznick, menuliskan bahwa hampir semua negara dunia ketiga menggunakan politik hukum ortodoks, dimana hukum semata-mata menjadi alat legitimasi keinginan aktor penguasa atau alat legal untuk menyalahgunakan kekuasaan.

Indonesia baik pada pemerintah Orde Baru maupun pemerintah reformasi serta kabinet persatuan dan gotong royong, kecendrungannya menggunakan politik hukum ortodoks. Peranan negara yang begitu kuat dalam pentas perpolitikan di Indonesia yang kemudian menarik banyak ilmuan politik dan hukum ketatanegaraan untuk memberikan penjelasan teoritis atau menyoroti kondisi negara Indonesia dari perspektif konstitusional.

Apabila kita ingin keluar dari situasi keterpurukan hukum, jawabannya adalah: merubah politik hukum pemerintah; membebaskan diri dari belenggu positivisme. Karena positivisme yang legalistik-positivistis berbasis pada peraturan tertulis (rule bound), tidak akan pernah menangkap hakikat kebenaran, karena baik dari sisi historis maupun filosofis yang melahirkannya, tidak mau melihat dan mengakui hal itu.

Mengapa demikian? Karena tidak semua hukum yang lahir dari keinginan pihak yang berdaulat. Kebiasaan-kebiasaan atau praktek hukum yang diperkenalkan oleh pengadilan sama sekali tidak merupakan ungkapan keinginan pihak yang berdaulat. Oleh karena itu pula, hukum tatanegara tidak dapat digolongkan ke dalam perintah yang berdaulat. Hukum tatanegara tidak dapat digolongkan ke dalam perintah yang berdaulat. Hukum tatanegara dari satu negara dapat didefinisikan sebagai kekuasaan dari berbagai alat negara (orgaan staaf), termasuk kekuasaan dari kedaulatan politik. Produk hukum yang didominasi oleh pemerintah tidak akan aspiratif, bahkan lebih dari itu kebijakan legislasi nasional yang mengutamakan kodifikasi dan unifikasi hukum cenderung mematikan nilai-nilai atau kaidah-kaidah yang bersumber dan tumbuh dalam masyarakat.

Berkaitan dengan hukum yang tumbuh atau hidup (living law) dalam masyarakat Teubner, ${ }^{5}$ menyatakan bahwa hal yang sangat mendasar dalam bidang hukum adalah kemandirian hukum, kamandirian dalam arti hukum harus merupakan legitimasi keinginan atau nilai-nilai yang hidup dan tumbuh dalam masyarakat hukum yang mengakomodasi keinginan masyarakat akan menjadi hukum

"Dias, Law and Administration In Altemative Development: Some Issues Choise and Strategies, (Washington University: 1989), hlm. 23

${ }^{5}$ Gunther Teubner, "Subtantive and Reflexsive Elements in Modern Law," Law and Society Review, Volume 17 Nomor 2. 
yang memenuhi asas keadilan, kemanfaatan serta kepastian. Hukum sebagai suatu sistem yang mempertahankan eksistensinya dari waktu ke waktu dan menyediakan suatu fungsi sosial akan tetap memperoleh independensi selama tarik ulur kepentingan dimenangkan oleh keadilan untuk masyarakat banyak. Sejalan dengan itu, Achmad Ali6 dalam menyatakan bahwa kemandirian hukum berakar pada cara-cara dimana semua pranata hukum, pola-pola penalaran, aturanaturan pengambilan keputusan dan asasnya harus bermuara pada keadilan, itulah sebabnya Charles Samford menyatakan bahwa hukum yang ideal adalah hukum yang mampu memuaskan semua pihak. ${ }^{7}$

Hukum yang dapat memuaskan semua pihak menurut Teubner adalah hukum yang responsif dan hukum yang responsif hanya dapat lahir jika ada demokratisasi legislasi. Tanpa demokratisasi (partisipasi masyarakat) ${ }^{9}$ dalam proses legislasi, hasilnya tidak akan pernah melahirkan hukum yang mandiri. Hukum hanya sebagai legitimasi keinginan pemerintah, dalam kondisi seperti itu ada tindakan pemerintah dianggap bertentangan dengan hukum. Kepentingan-kepentingan masyarakat menjadi terabaikan, apa yang oleh masyarakat umum dianggap sebagai norma atau kaidah, oleh pemerintah dianggap bertentangan dengan hukum nasional.

Hukum bersifat mandiri karena maknamaknanya mengacu pada dirinya sendiri (keadilan, kemanfaatan dan kepastian). Model hukum semacam inilah yang diharapkan untuk menciptakan konsep Indonesia baru hukum secara substansial harus merujuk pada kaidah/norma dasar yang mengakomodasi nilai-nilai keadilan.

Sebagai negara hukum yang telah menentukan Pancasila sebagai falsafah dan UUD 1945 sebagai dasar negara, maka semua aturan kenegaraan harus bersumber atau dijiwai oleh Pancasila dan UUD 1945. Begitu penting dan mendasarnya falsafah dan dasar negara tersebut, harus dilakukan dengan pemikiran yang betul-betul komprehensif, arif dan bijaksana. Harapannya adalah falsafah dan dasar negara tersebut dapat dijadikan landasan untuk menuju masyarakat adil dan makmur. Persoalannya adalah apakah kita berani melakukan koreksi lebih lanjut UUD 1945 (UUD kilat hanya membutuhkan waktu 81 hari mulai persiapan sampai diundangkannya). Tidak ada pilihan dengan menggunakan pisau analisis keadilan UUD 1945 harus ditinjau ulang termasuk pasal yang telah diamandemen khususnya Pasal 20 dan 21. Berbagai hal yang mendasar sesuai perkembangan lingkungan yang strategis harus diatur dalam konstitusi dasar.

Kehidupan bangsa Indonesia saat ini sedang menuju ke arah anomi, baik secara personal, sosial maupun institusional. Anomi adalah suatu keadaan dimana manusia sudah tidak tahu lagi standar prilaku yang harus diterapkan atau state normlesnes. ${ }^{10}$ Pada

Achmad Ali, op.cit., him. 28

${ }^{7}$ Charles Sampford, The Disorder oflaw, Critical Legal Theory, (New York: Basil Bacwell, 1989), hlm. 113

- Teubner, loc. cit.

${ }^{9}$ Demokratisasi legislasi adalah melibatkan masyarakat dalam proses legislasi, mulai tahap perencanaan, penyusunan sampai kepada pelaksanaan hukum hasil dari proses legislasi. Demokratisasi juga bermakna pemberdayaan masyarakat dalam hukum.

${ }^{10}$ Achmad Ali, op.cit., hlm. 29 
tataran personal, seorang manusia gampang mencurigai manusia lain, gampang berperilaku seenaknya sendiri, seolah-olah tidak ada lagi aturan-aturan yang dapat dijadikan pegangan dan kebenaran. Tindakan-tindakan tersebut seperti: menghujat, memfitnah, menjarah, membunuh, main hakim sendiri (eigenrichting) dan lainlain. Bahkan tindakan-tindakan pembunuhan gampang dilakukan di tengah-tengah definisi yang berlaku bahwa kita adalah bangsa yang beradab. Pada tataran sosial, bangsa ini sedang mengembangkan dan menerapkan kehidupan homogen komunal dan membabi buta (blind communal homogeneous society). Sentimen untuk seorang personal dianggap sebagai sentimen kelompok. Ketersinggungan personal disamakan dengan ketersinggungan kelompok. Akibatnya peran antar kelompok yang bernuansa SARA sangat gampang terjadi bahkan menjadi suatu trend baru dalam kehidupan bangsa ini. Pada tataran institusional tampak ketidakmampuan lembaga-lembaga penegak hukum untuk mencegah anomytrend seperti itu. Aparat menegak hukum (polisi, jaksa, hakim dan profesi advokat) sangat tidak berdaya untuk melaksanakan fungsi-fungsi penegakan hukum yang tentu saja tidak hanya menciptakan formal justice, tetapi juga substantial justice. Kita menyadari bahwa kita dan hukum kita lebih banyak berkutat bagaimana menciptakan formal justice ketimbang substantial justice. Akibatnya hukum hanya berurusan dengan hak-hal teknis semata dan technological, sentuhan kemanusiaan dari hukum menjadi hilang. Hukum direduksi menjadi dua hal yang jukstaposisional seperti: benar-salah, hitam-putih, menang-kala, halalharam, bayar-tidak bayar. ${ }^{11}$

\section{Kepastian Hukum vs Kepastian Undang- Undang}

Kepastian hukum (rechtszekerhied, legal certainty) merupakan asas penting dalam tindakan hukum (rechtshandeling) dan penegakan hukum (rechtshandhaving, law enforcement). Telah menjadi pengetahuan umum bahwa peraturan perundang-undangan dapat memberikan kepastian hukum lebih tinggi daripada hukum kebiasaan, hukum adat atau hukum yurisprudensi. Namun perlu diketahui pula bahwa kepastian hukum peraturan perundang-undangan tidak sematamata diletakkan dalam bentuknya yang tertulis (geschreven). Menurut Bagir Manan, untuk benar-benar menjamin kepastian hukum suatu peraturan perundang-undangan, selain memenuhi syarat-syarat formal, harus pula memenuhi syarat-syarat lain yaitu: jelas dalam perumusannya (unambiguous); konsisten dalam perumusannya baik secara intern maupun ekstern; penggunaan bahasa yang tepat dan mudah dimengerti. ${ }^{12}$

Undang-undang hanyalah salah satu bagian dari unsur peraturan perundangundangan dan hukum substansi yang mencakupi aturan-aturan hukum, baik yang tertulis (written) maupun tidak tertulis (unwritten), termasuk putusan peradilan (judge made law). Selain unsur substansi hukum (legal-sub-

\section{1 lbid.}

${ }^{12}$ Bagir Manan, Pembinaan Hukum Nasional, (Bandung: Alumni 2000), hlm. 225 
stantial) masih ada lagi unsur struktur hukum (legal-structur) dan unsur budaya hukum (legal-cultural). ${ }^{13}$

Pada saat yang bersamaan, kita dihadapkan oleh kenyataan bahwa kita semakin banyak ditaburi oleh berbagai peraturan perundang-undangan yang semuanya untuk mengatur perilaku manusia. Peraturan perundang-undangan (algemene verbindende voorschriften) semakin hari semakin bertambah, sehingga tidaklah berlebihan apabila dikatakan, bangsa ini sedang memasuki suatu kondisi hiperregulated society. Pertanyaan besarnya ialah mengapa setelah dihadapkan dengan berbagai peraturan perundang-undangan dan aturan kebijakan (beleidsrege/s) yang sebanyak itu, ketertiban (order) tidak kunjung datang jua, justru hukum tampak semakin tidak ada harapan (hopeless) dan kedodoran, sehingga penyelesaian hukumpun justru menciptakan persoalan baru ketimbang menuntaskan atau menyelesaikan masalah.

Berkaca dari kondisi objektif yang demikian, sudah saatnya dipikirkan pergeseran fungsi peradilan dari fungsi mengadili perkara menjadi fungsi menyelesaikan/menuntaskan perkara. Peristiwa yang berkaitan dengan socio-legal tidak cukup sekedar diselesaikan oleh undang-undang, olehnya itu paradigma yang melihat hukum hanya sebatas undangundang sudah saatnya diubah dan ditinggalkan. Kepastian undang-undang tidak identik dan jangan diidentikkan dengan kepastian hukum.

\section{Persamaan vs Keadilan}

Penegakan hukum pada masyarakat yang relatif homogen di bidang politik, ekonomi, sosial dan budaya, semestinya berbeda dengan penegakan hukum pada masyarakat majemuk (bhineka). Pada masyarakat mejemuk, politik hukum penegakan hukum yang serba menyamakan (uniformitas) dapat menimbulkan masalah politik, ekonomi maupun sosial. Karena itu politik hukum seperti unifikasi harus dipertimbangkan dengan matang kemanfaatannya pada masyarakat majemuk (heterogen). Secara normatif dan idiologis diakui ada beberapa segi positif dari suatu politik unifikasi antara lain:

(a) Penyederhanaan hukum. Suatu unifikasi akan mewujudakn sistem dan struktur hukum yang sederhana. Sistem dan struktur hukum yang sederhana sangat penting dalam mencapai kepastian hukum dan keadilan hukum dalam penerapan dan penegakannya.

(b) Unifikasi merupakan instrumen untuk mewujudkan prinsip persamaan di depan hukum (equality before the law), persamaan pelayanan hukum dan perlakuan hukum tanpa membedabedakan masyarakat meskipun persamaan itu belum tentu dapat membawa pada keadilan.

(c) Unifikasi merupakan instrumen untuk secara bertahap meniadakan kemajemukan menuju suatu masyarakat homogen.

${ }^{13}$ M. Lawrence, Friedmann, The Legal Syatem, A Social Science Perspective, (New York: Russel Sage Foundọtion, 1975), h/m. 37 
Namun secara sosiologis, tujuan-tujuan normatif unifikasi tersebut tidak selalu mencapai tujuan bahkan dapat terjadi sebaliknya. Memaksakan persamaan pada masyarakat yang berbeda malahan dapat terjadi sebaliknya. Memaksakan persamaan pada masyarakat yang berbeda malahan dapat menimbulkan ketidakpastian hukum dan ketidakadilan. Unifikasi hukum yang tidak mempertimbangkan kenyataan-kenyataan yang hidup dalam masyarakat justru menimbulkan ketidakpatuhan terhadap hukum karena merasa asing dan merasakan ketidakadilan.

Berbeda halnya jika hukum yang diberlakukan itu didasarkan pada moralitas, kultural dan religiusnya, masyarakat akan merasakan hukum itu cocok dengan nilai-nilai instrinsik yang mereka anut. Sepanjang aturan hukum yang ada tidak sesuai dengan nilainilai instrinsik warga masyarakat, maka ketaatan hukum yang muncul hanyalah sekedar ketaatan yang bersifat compliance (taat karena hanya takut sanksi). Dan bukan ketaatan yang bersifat internalization (taat kàrena benar-benar menganggap aturan hukum itu cocok dengan nilai instrinsi yang dianutnya). Sebagai contoh, di lapangan hukum ekonomi dan perdagangan, yang mempersamakan kemampuan bersaing pengusaha kecil dan pengusaha besar. Tanpa peraturan khusus yang memberikan perlindungan pada pengusaha kecil, mereka telah dan akan habis ditelan oleh pengusaha besar. Hasilnya saat ini ialah kehidupan ekonomi terkonsentrasi pada sejumlah pengusaha besar yang menimbulkan kesenjangan (gap) dan menghasilkan ketegangan-ketegangan yang sangat potensial. Mempengaruhi corak kehidupan politik, sosial masyarakat secara keseluruhan.

Persamaan hukum tidak selalu berarti keadilan. Perbedaan hukum tidak selalu berarti ketidakadilan. Keadilan dan kemanfaatan hukum akan terletak pada persamaan pada tempat dimana diperlukan persamaan dan perbedaan pada tempat diperlukan perbedaan.

\section{Simpulan}

Penegakan hukum dan penerapan hukum adalah tugas utama pemerintah yang diserahkan kepada institusi dan aparat penegak hukum yang membutuhkan dukungan masyarakat secara keseluruhan sebagai tempat berlakunya hukum.

Penegakan hukum dan penerapan hukum hanya dapat dilakukan dalam pemerintahan dan masyarakat bangsa yang demokratis serta masyarakat yang memahami apa yang menjadi hak dan kewajibannya.

Penegakan hukum tidak dapat berjalan sendiri, tetapi selalu terkait dengan politik hukum, pembaharuan hukum, sistem hukum dan kesamaan persepsi terhadap hukum yang akan ditegakkan.

Keterpurukan hukum di Indonesia akibat merosotnya tingkat kepercayaan masyarakat terhadap pemerintah secara umum dan khususnya aparat penegak hukum.

Solusi untuk keluar dari keterpurukan hukum saat ini, adalah dibutuhkan kesadaran hukum, kesadaran berbangsa, bernegara yang bersandarkan pada nilai-nilai moral, kuitural dan spritual dari seluruh komponen bangsa. 


\section{Daftar Pustaka}

Manan, Bagir, Pembinaan Hukum Nasional, Bandung: Alumni, 2000.

Black, Donald, The Behavior of Law, Academic Press, Inc. 1976

Friedmann, Lawrence. M., The Legal System: A Society Science Perspective, New York: Russel Sage Foundation, 1975.

James CN. Paul Clarance Dias, Law and. Adminitration in Alternative Development: Someissues Choice and Strate- gies, Washington: University, 1989.

Philippe, Nonet, dan Philippe Selznick, Law and Society in Transition Toward Responsive Law, New, York: Harper Colophon Book, 1987.

Joseph, Raz The Concept of A Legal System, New York: Clarandon Press Oxford. 1980.

Teubner, Gunther, "Subtantive and Reflexsive Elements in Modern Law", Law and Sociaty Review, Volume 17 No. 2, 1983. 